\title{
Design and Synthesis of Three Tetracyclic-Dione Derivatives and their Biological Activity on Perfusion Pressure Using an Isolated Rat Heart Model
}

\author{
Figueroa-Valverde Lauro ${ }^{1, *(\mathbb{D})}$, Díaz-Cedillo Francisco ${ }^{2 \mathbb{D}}$, Rosas-Nexticapa Marcela ${ }^{3}{ }^{\mathbb{D}}$, Mateu-Armad

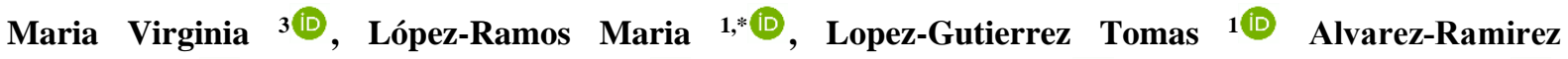 \\ Magdalena ${ }^{3(D)}$, Estrella-Barron Raquel ${ }^{4}$ (D), Arakachi-Cruz Idalia 5(D), Salgado-Alarcon Kelly 5 (D), \\ Cauich-Carrillo Regina 1 (iD \\ 1 Laboratory of Pharmaco-Chemistry, Faculty of Chemical Biological Sciences, University Autonomous of Campeche, Av. \\ Agustín Melgar s/n, Col Buenavista C.P. 24039 Campeche, Camp., México \\ 2 Escuela Nacional de Ciencias Biológicas del Instituto Politécnico Nacional. Prol. Carpio y Plan de Ayala s/n Col. Santo \\ Tomas, D.F. C.P. 11340, México \\ 3 Facultad de Nutrición, Universidad Veracruzana, Médicos y Odontologos s/n C.P. 91010, Unidad del Bosque Xalapa \\ Veracruz, México \\ 4 Universidad Autónoma del Carmen, Facultad de Ciencias de la Salud Campus III, Av. Central s/n Esq. Fracc. Mundo \\ Maya, C.P. 24153 Ciudad del Carmen, Campeche, Mexico \\ 5 Modelo University, Campus Chetumal, Carretera Federal Chetumal-Subteniente Lopez s/n, Quintana Roo, Mexico \\ * Correspondence: Ifiguero@uacam.mx (F.V.L); maclopez@uacam.mx (R.N.M);
}

Scopus Author ID 55995915500

Received: 25.02.2021; Revised: 2.04.2021; Accepted: 6.04.2021; Published: 20.04.2021

Abstract: Several tetracyclic derivatives have been prepared with different biological activity; however, there are few reports on the effects exerted by the tetracyclic derivatives on the cardiovascular system. The objective of this investigation was to prepare three tetracyclic-dione derivatives (compounds 3 to 5) to evaluate their biological activity on perfusion pressure and coronary resistance. The first stage was achieved by the synthesis of three tetracyclic-dione analogs using some chemical strategies. The second stage involves evaluating biological activity from tetracyclic-derivatives on perfusion pressure and coronary resistance using an isolated rat heart model. The results showed that only compound 5 increases perfusion pressure and coronary resistance compared with the control conditions. In conclusion, the biological activity of compound 5 exerted against perfusion pressure and coronary resistance depends on the functional groups involved in their chemical structure.

Keywords: tetracyclic; derivatives; chemical; perfusion pressure.

(C) 2021 by the authors. This article is an open-access article distributed under the terms and conditions of the Creative Commons Attribution (CC BY) license (https://creativecommons.org/licenses/by/4.0/).

\section{Introduction}

For several years, tetracyclic compounds have been of great interest to the pharmaceutical and chemical industry [1-10]. For example, the synthesis of some tetracyclic 1,5-benzodiazepine derivatives from nevirapine as virus de immunodeficiency human inhibitors using MT-4 cells [11]. Another report displays the preparation of a benzofurane derivative via reaction of 2-Amino-benzoic acid with biological activity against cancer [12]. Also, a study showed the reaction of 3-aryl coumarin aldehydes with malononitrile to form some 3-arylcumarin-tetracyclic derivatives, which were used for the treatment of Parkinson's [13]. Other studies showed the preparation of a tetracyclic thienopyridone from 4oxopyrido[3',2':4,5]thieno[3,2- $b]$ indole-3-carboxylic acid as antibacterial and antitumor agents 
[14]. Besides, a report showed the preparation of some tetracyclic fluoroquinolones as antibacterial and anticancer agents [15].

On the other hand, some studies indicate that some tetracyclic exert biological activity on the cardiovascular system; thus, a study suggests that a tetracyclic drug such as imipramine exerts changes in coronary vascular responses in an isolated perfused rat heart model [16]. Other studies showed the synthesis of 2-(4-Substituted-phenyl)sparteine from a 2dehydrosparteine derivative as an inotropic agent in an isolated guinea pig atria [17]. A report showed some tetracyclic guanines can decrease blood pressure in a spontaneously hypertensive rat model [18]. These data indicate that tetracyclic derivatives can exert an effect on the cardiovascular system; however, there are little data on the biological activity induced by tetracycl-dione derivatives on the cardiovascular system; in this way, this investigation aimed to synthesize three tetracycl-dione derivatives to evaluate their biological activity on perfusion pressure and resistance vascular using an isolated rat heart model.

\section{Materials and Methods}

\subsection{General.}

The epoxide derivative (compound 1) was prepared using a previously reported method [19]. Also, the reagents used in this research were acquired from Sigma-Aldrich Co., Ltd. Melting point was determinate using an Electrothermal (900 models) apparatus. Infrared spectra (IR) were obtained with a Thermo Scientific iSOFT-IR spectrometer. ${ }^{1} \mathrm{H}$ and ${ }^{13} \mathrm{C}$ NMR spectra were recorded using a Varian VXR300/5 FT NMR spectrometer at $300 \mathrm{MHz}$ in deutered chloroform $\left(\mathrm{CDCl}_{3}\right)$ using tetramethylsylane as an internal standard. Electron ionization-mass spectrometry (EIMS) were obtained with a Finnigan Trace Gas Chromatography Polaris Q-Spectrometer. Elementary analysis data were determinate with a Perkin Elmer Ser. II CHNS/02400 elemental analyzer.

\subsubsection{Synthesis.}

\section{(4R,6S)-11-[hydroxy(phenyl)methyl]-5-oxapentacyclo[7.4.1.02,8.04,6.010,13]tetradec- 10(13)-ene-3,7-dione (2).}

A solution of compound $1(100 \mu 1,0.52 \mathrm{mmol}), 1$-phenyl-2-propyn-1-ol (80 $\mu 1,0.65$ $\mathrm{mmol})$, Copper(II) chloride anhydrous $(130 \mathrm{mg}, 0.96 \mathrm{mmol})$ in methanol $(5 \mathrm{ml})$ was stirring for $72 \mathrm{~h}$ at room temperature. Then, the solvent of mixture was evaporated under reduced pressure and following the product was purified trough a crystallization using the methanol:agua (3:1:1) system; yielding $54 \%$ of product; m.p. $56-58{ }^{\circ} \mathrm{C}$; IR $\left(V_{\max }, \mathrm{cm}^{-1}\right) 3400$ and 1712: ${ }^{1} \mathrm{H}$ NMR $\left(300 \mathrm{MHz}, \mathrm{CDCl}_{3}-d\right) \delta_{\mathrm{H}}$ : 1.44-1.66 (m, 2H), 2.52 (broad, $\left.1 \mathrm{H}\right), 2.56-2.62$ (m, 2H), 2.68-2.70 (m, 2H), 3.20-3.32 (m, 4H), $3.60(\mathrm{~m}, 2 \mathrm{H}), 4.36(\mathrm{~m}, 1 \mathrm{H}), 7.14-7.40(\mathrm{~m}, 5 \mathrm{H})$ ppm. ${ }^{13} \mathrm{C} \mathrm{NMR}\left(300 \mathrm{~Hz}, \mathrm{CDCl}_{3}\right) \delta_{\mathrm{C}}: 26.92,41.20,46.50,47.42,48.74,52.12,53.27,65.96$, 80.25, 126.44, 126.48, 128.60, 129.16, 139.80, 139.98, 204.86 ppm. EI-MS m/z: 322.12. Anal. Calcd. for $\mathrm{C}_{20} \mathrm{H}_{18} \mathrm{O}_{4}$ : C, 74.52; H, 5.63; O, 19.85. Found: C, 74.50; H, 5.60.

\section{5-(3-ethynylanilino)-4-hydroxy-10-[hydroxy(phenyl)methyl]tetracyclo[6.4.1.02,7.09, 12]tridec-9(12)-ene-3,6-dione (3).}

A solution of compound 2 (165 mg, $0.51 \mathrm{mmol}), 3$-ethynylaniline (100 $\mu 1,0.52 \mathrm{mmol})$, triethylamine $(100 \mu \mathrm{l}, 0.71 \mathrm{mmol})$, water $(5 \mathrm{ml})$; following the solution was adjusted at a $\mathrm{pH}$ of 8.0 and then was stirring for $4 \mathrm{~h}$ to reflux. Then, the solvent of mixture was evaporated under reduced pressure and following the product was purified via crystallization using the 
methanol:hexane:agua (3:1:1) system; yielding $54 \%$ of product; m.p. $62-64{ }^{\circ} \mathrm{C}$; IR ( $V_{\max }$, $\left.\mathrm{cm}^{-1}\right)$ 3400, 3312 and 1712: ${ }^{1} \mathrm{H}$ NMR $\left(300 \mathrm{MHz}, \mathrm{CDCl}_{3}-d\right) \delta_{\mathrm{H}}: 1.44-1.66(\mathrm{~m}, 2 \mathrm{H}), 2.54(\mathrm{~m}$, $1 \mathrm{H}), 2.56-2.62(\mathrm{~m}, 2 \mathrm{H}), 2.86(\mathrm{~s}, 1 \mathrm{H}), 2.88(\mathrm{~m}, 1 \mathrm{H}), 3.15(\mathrm{broad}, 3 \mathrm{H}), 3.20(\mathrm{~m}, 1 \mathrm{H}), 3.22-3.34$ $(\mathrm{m}, 2 \mathrm{H}), 4.36(\mathrm{~m}, 1 \mathrm{H}), 4.48-4.50(\mathrm{~m}, 2 \mathrm{H}), 6.60-6.64(\mathrm{~m}, 2 \mathrm{H}), 7.14(\mathrm{~m}, 1 \mathrm{H}), 7.16-7.25(\mathrm{~m}, 2 \mathrm{H})$, 7.32-7.40 (m, 4H) ppm. ${ }^{13} \mathrm{C}$ NMR $\left(300 \mathrm{~Hz}, \mathrm{CDCl}_{3}\right) \delta_{\mathrm{c}}: 26.92,41.20,45.90,46.50,50.55$, $53.10,54.70,67.12,76.82,78.20,80.22$, 84.00, 117.84, 121.00, 121.76, 125.50, 126.44, 126.48, 128.60, 129.12, 129.16, 139.80, 139.95, 150.12, 201.44, 202.80 ppm. EI-MS m/z: 439.17. Anal. Calcd. for $\mathrm{C}_{28} \mathrm{H}_{25} \mathrm{NO}_{4}$ : C, 76.52; H, 5.73; N, 3.19; O, 14.56. Found: C, 76.50; H, 5.70 .

\section{4-hydroxy-10-[hydroxy(phenyl)methyl]-5-(prop-2-ynylamino)tetracyclo[6.4.1.02, 7.09,12] tridec-9(12)-ene-3,6-dione (4)}

A solution of compound $2(165 \mathrm{mg}, 0.51 \mathrm{mmol})$, propargylamine $(50 \mu 1,0.78 \mathrm{mmol})$, 5 triethylamine $(100 \mu \mathrm{l}, 0.71 \mathrm{mmol})$, water $(5 \mathrm{ml})$; following the solution was adjusted at a $\mathrm{pH}$ of 8.0 and then was stirring for $4 \mathrm{~h}$ to reflux. Then, the solvent of mixture was evaporated under reduced pressure and following the product was purified trough a crystallization using the methanol:hexane:agua (3:1:1) system;yielding $54 \%$ of product; m.p. $98-100{ }^{\circ} \mathrm{C}$; IR $\left(V_{\max }\right.$, $\mathrm{cm}^{-1}$ ) 3400, 2122 and 1712: ${ }^{1} \mathrm{H}$ NMR $\left(300 \mathrm{MHz}, \mathrm{CDCl}_{3}-d\right) \delta \mathrm{H}:$ : 1.44-1.66 (m, 2H), $2.02(\mathrm{~s}$, $1 \mathrm{H}), 2.28$ (broad, 3H), $2.54(\mathrm{~m}, 1 \mathrm{H}), 2.56-2.62(\mathrm{~m}, 2 \mathrm{H}), 2.76(\mathrm{~m}, 1 \mathrm{H}), 3.20(\mathrm{~m}, 1 \mathrm{H}), 3.22-3.24$ $(\mathrm{m}, 2 \mathrm{H}), 3.52-3.54(\mathrm{~m}, 2 \mathrm{H}), 3.70(\mathrm{~m}, 1 \mathrm{H}), 4.36(\mathrm{~m}, 1 \mathrm{H}), 4.46(\mathrm{~m}, 1 \mathrm{H}), 7.16-7.40(\mathrm{~m}, 5 \mathrm{H}) \mathrm{ppm}$. ${ }^{13} \mathrm{C} \mathrm{NMR}\left(300 \mathrm{~Hz}, \mathrm{CDCl}_{3}\right) \delta \mathrm{c}: 26.92,35.94,41.20,46.50,49.12,50.58,54.74,55.98,71.62$, 73.44, 76.92, 78.32, 80.20, 126.42, 126.48, 128.60, 129.12, 139.80, 139.96, 197.44, 201.60 ppm. EI-MS m/z: 377.16. Anal. Calcd. for $\mathrm{C}_{23} \mathrm{H}_{23} \mathrm{NO}_{4}$ : C, 73.19; H, 6.14; N, 3.71; O, 16.96 . Found: C, 73.16; H, 6.12.

\section{4-hydroxy-10-[hydroxy(phenyl)methyl]-5-(2-phenylhydrazino)tetracyclo[6.4.1.02,7. 09,12] tridec-9(12)-ene-3,6-dione (5)}

A solution of compound $2(165 \mathrm{mg}, 0.51 \mathrm{mmol})$, phenylhydrazine $(80 \mu \mathrm{l}, 0.81 \mathrm{mmol})$, 5 triethylamine $(100 \mu \mathrm{l}, 0.71 \mathrm{mmol})$, water $(5 \mathrm{ml})$; following the solution was adjusted at a $\mathrm{pH}$ of 8.0 and then was stirring for $4 \mathrm{~h}$ to reflux. Then, the solvent of mixture was evaporated under reduced pressure and following the product was purified via crystallization using the methanol:agua (3:1:1) system; yielding 54\% of product; m.p. $138-140{ }^{\circ} \mathrm{C}$; IR $\left(V_{\max }, \mathrm{cm}^{-1}\right) 3402$, 3380, 3310 and 1710: ${ }^{1} \mathrm{H}$ NMR (300 MHz, $\left.\mathrm{CDCl}_{3}-d\right) \delta_{\mathrm{H}}: 1.44-1.66(\mathrm{~m}, 2 \mathrm{H}), 2.54(\mathrm{~m}, 1 \mathrm{H})$, 2.56-2.62 (m, 2H), $2.76(\mathrm{~m}, 1 \mathrm{H}), 3.20(\mathrm{~m}, 1 \mathrm{H}), 3.22-3.36(\mathrm{~m}, 2 \mathrm{H}), 3.96(\mathrm{~m}, 1 \mathrm{H}), 4.36(\mathrm{~m}, 1 \mathrm{H})$, 4.40 (m, 1H), 4.72 (broad, 4H), 6.90-6.92 (m, 3H), $7.12(\mathrm{~m}, 1 \mathrm{H}), 7.24(\mathrm{~m}, 2 \mathrm{H}), 7.32-7.40(\mathrm{~m}$, $4 \mathrm{H})$ ppm. ${ }^{13} \mathrm{C} \mathrm{NMR}\left(300 \mathrm{~Hz}, \mathrm{CDCl}_{3}\right) \delta \mathrm{C}: 26.92,41.20,46.50,46.70,50.58,54.74,54.84$, $60.32,73.76,80.20,111.40,121.52,126.26,126.44,126.48,128.60,129.12$, 139.80, 139.96, 148.10, 200.40, 200.44 ppm. EI-MS m/z: 430.18. Anal. Calcd. for $\mathrm{C}_{26} \mathrm{H}_{26} \mathrm{~N}_{2} \mathrm{O}$ : $\mathrm{C}, 72.54 ; \mathrm{H}$, 6.09; N, 6.51; O, 14.87. Found: C, 72.50; H, 6.06.

\subsubsection{Pharmacophore evaluation.}

The 3D pharmacophore model for both compounds 3-5 was determined using LigandScout 4.08 software [20].

\subsubsection{Pharmacokinetic parameters.}

SwissADME [21] was used to evaluate some pharmacokinetics parameters for either compounds 3-5. 


\subsection{Biological activity.}

\subsubsection{Generalities.}

Experimental methods used in this study were are based on rules approved by the Animal Care and Use Committee of University Autonomous of Campeche and accord to Guide for the Care and Use of Laboratory Animals [22]. Male rats Wistar, weighing 200-250 g, were obtained from Laboratory from the pharmacochemistry of University Autonomous of Campeche.

\subsubsection{Reagents.}

All drugs were dissolved in methanol. Then, the dilutions were carried out using KrebsHenseleit solution $(0.01 \%$, v/v, which was prepared using a previously reported study [23].

\subsubsection{Langendorff method.}

Animals) were anesthetized intraperitoneally with pentobarbital ( $50 \mathrm{mg} / \mathrm{Kg}$ ). Then the chest was opened, and a loose ligature passed through the ascending aorta. Following, the heart was removed and immersed in Krebs-Henseleit solution. Then, the heart was trimmed of noncardiac tissue and retrograde perfused through a non-circulating perfusion system at a constant flow rate using a peristaltic pump. An initial perfusion rate of $15 \mathrm{ml} / \mathrm{min}$ for $5 \mathrm{~min}$ was followed by a $25 \mathrm{~min}$ equilibration period at a perfusion rate of $10 \mathrm{ml} / \mathrm{min}$. It is important to mention that all determinations were done after this equilibration period.

\subsubsection{Perfusion pressure.}

Perfusion pressure changes were carried out in the absence or presence of drugs involved in this study using a pressure transducer connected to the chamber where the hearts were mounted. The records obtained were entered into a computerized data capture system (Biopac).

\subsubsection{Experimental design.}

Thirty-two animals were used, 8 for each group control and treatment groups. The control group received no drug, while the treatment group functioned as its control.

2.2.5.1. Biological activity exerted by tetracyclic-dione derivatives (3, 4, and 5) on perfusion pressure.

Differences in perfusion pressure ( 3 to $18 \mathrm{~min}$ ) in the absence (control) or presence of either compounds 3 or 4 , or 5 at a concentration of $0.001 \mathrm{nM}$ were evaluated. It is noteworthy that the effects were obtained in isolated hearts perfused at a constant flow rate of $10 \mathrm{ml} / \mathrm{min}$.

2.2.5.2. Biological activity produced by tetracyclic-dione derivatives $(3,4$, and 5)on coronary resistance.

In this investigation, coronary resistance was evaluated in the absence (control) of either compounds 3 or 4 , or 5 at a concentration of $0.001 \mathrm{nM}$. It is noteworthy that coronary resistance was determined as the relationship between coronary flow and perfusion pressure $(\mathrm{mm} \mathrm{Hg} / \mathrm{ml}$ /min). 


\subsubsection{Statistical analysis.}

The data are expressed as average $\pm \mathrm{SE}$. The results were put under the variance analysis (ANOVA) with the Bonferroni correction factor using the SPSS 12.0 program [23]. The differences were considered significant when $p$ was equal to or smaller than 0.05 .

\section{Results and Discussion}

Several compounds have been synthesized to evaluate their activity on the cardiovascular system; however, several protocols use some reagents which require special conditions such as differences in either temperature or $\mathrm{pH}$ [11-18]. In this investigation, three tetracyclic derivatives were prepared to evaluate their biological activity against perfusion pressure and vascular resistance using an isolated rat heart model. The first stage was carried out as follows:

\subsection{Chemistry.}

\subsubsection{Preparation of a cyclobutene derivative.}

Some studies have shown the preparation of cyclobutene analogs via $[2+2]$ cycloaddition of an alkene with alkyne groups or cycloaddition of alkyne groups to alkyne derivatives using some reagents such as ruthenium [24], $\mathrm{Ni}\left(\mathrm{PPh}_{3}\right)_{2} \mathrm{Cl}_{2}$ [25], Cobalt [26] and others; however, some protocols require special conditions such as differences in either $\mathrm{pH}$ and temperature. In this way, compound 2 was prepared via a reaction of 1 with 1-phenyl-2-propyn1-ol, in the presence of Copper(II) chloride (Figure 1). The ${ }^{1} \mathrm{H}$ NMR spectrum from 2 showed several signals at $0.80 \mathrm{ppm}$ for methyl group; at 1.44-1.66, 2.56-2.62, 2.68-2.70 and 3.20-3.32 ppm for Tricyclo[4.2.1.02,5]non-2(5)-ene; at $2.52 \mathrm{ppm}$ for hydroxyl group; at $4.36 \mathrm{ppm}$ for methylene bound to both hydroxyl and phenyl groups; at 7.14-7.40 ppm for phenyl group. ${ }^{13} \mathrm{C}$ NMR spectra showed chemical shifts at 26.92-53.27 and $128.60 \mathrm{ppm}$ for Tricyclo[4.2.1.02,5]non-2(5)-ene; at 65.96 and $139.80 \mathrm{ppm}$ for cyclohexane ring; at $80.25 \mathrm{ppm}$ for methylene bound to hydroxyl and phenyl groups; at 126.44-126.48, 129.16 and 138.98 ppm for phenyl group; at 204.86 ppm for ketone group. Besides, the mass spectrum from 2 showed a molecular ion $(\mathrm{m} / \mathrm{z}) 322.12$.

\subsubsection{Epoxide ring opening.}

There are several reagents used to promote epoxides ring-opening such as alumina [27], transition metal-based Lewis acids [28], lithium bistrifluoromethanesulfonimide [29], bismuth triflate [30], bismuth trichloride [31], zinc(II) perchlorate hexahydrate [32], diisopropoxyaluminium trifluoroacetate [33], vanadium(III) chloride and others. Most of these methodologies use expensive reagents that require special conditions. In this investigation, the epoxide ring-opening (compound 2) was produced under basic conditions via $\mathrm{SN}_{2}$ mechanism to form either compounds 3 or 4 or 5 (Figure 1). In this way, the ${ }^{1} \mathrm{H}$ NMR spectrum from 3 showed several signals at $0.80 \mathrm{ppm}$ for methyl group; at 1.44-1.66 2.56-2.62 and 3.20-3.34 ppm for Tricyclo[4.2.1.02,5]non-2(5)-ene; at 2.54, 2.88 and 4.48-4.56 for cyclohexane ring; at $2.86 \mathrm{ppm}$ for alkyne group; at $3.15 \mathrm{ppm}$ for both hydroxyl and amino groups; at $4.36 \mathrm{ppm}$ for methylene bound to both hydroxyl and phenyl groups; at 6.60-6.64 and 7.16-7.25 ppm for phenyl group bound to both amino and alkyne groups; at 7.14 and 7.32-7.40 ppm for phenyl group bound to a methylene group. ${ }^{13} \mathrm{C}$ NMR spectra showed chemical shifts at 26.92-54.70, 
128.60 and $139.80 \mathrm{ppm}$ for Tricyclo[4.2.1.02,5]non-2(5)-ene; at 67.12-76.82 ppm for cyclohexane ring; at 78.20 and $84.00 \mathrm{ppm}$ for alkyne group; at $80.22 \mathrm{ppm}$ for methylene group bound to hydroxyl group; at 117.84-125.50, 129.12 and $150.12 \mathrm{ppm}$ for phenyl group bound to both alkyne and amino groups; at 126.44-126.48, 129.16 and $139.95 \mathrm{ppm}$ for phenyl group bound to methylene group; at 201.44 and 202.80 ppm for ketone groups. In addition, the mass spectrum from 3 showed a molecular ion $(\mathrm{m} / \mathrm{z}) 439.17$.

Other data showed several signals involved in the ${ }^{1} \mathrm{H}$ NMR spectrum from 4 at 0.80 ppm for methyl group; at 1.44-1.66, 2.54-3.34 ppm for Tricyclo[4.2.1.02,5]non-2(5)-ene; at 3.70 and $4.46 \mathrm{ppm}$ for cyclohexane ring; at $2.28 \mathrm{ppm}$ for both hydroxyl and amino groups; at 3.52-3.54 ppm for methylene group bound to both amino and alkyne groups; at $4.36 \mathrm{ppm}$ for methylene bound to both hydroxyl phenyl groups; at 7.16-7.40 ppm for phenyl groups. ${ }^{13} \mathrm{C}$ NMR spectra showed chemical shifts at 26.92, 41.20-76.92, 128.60 and 139.80 ppm for Tricyclo[4.2.1.02,5]non-2(5)-ene; at $35.94 \mathrm{ppm}$ for methylene bound to both alkyne and amino groups; at 71.62 and $78.32 \mathrm{ppm}$ for alkyne group; at methylene bound to both hydroxyl and phenyl groups; at 126.42-125.48, 129.12 and 139.96 ppm for phenyl group; at 192.44 and $201.60 \mathrm{ppm}$ for ketone groups. Besides, the mass spectrum from 4 showed a molecular ion $(\mathrm{m} / \mathrm{z}) 377,16$.

Finally, the ${ }^{1} \mathrm{H}$ NMR spectrum from 5 showed several signals at $0.80 \mathrm{ppm}$ for methyl group; at 1.44-3.36 ppm for Tricyclo[4.2.1.02,5]non-2(5)-ene; at 3.96 and $4.40 \mathrm{ppm}$ for cyclohexane ring; at $4.72 \mathrm{ppm}$ for both amino and hydroxyl groups; at 6.90-6.92 and $7.26 \mathrm{ppm}$ for phenyl group bound to the amino group; at 7.12 and 7.32-7.40 ppm for phenyl group bound to a methylene group. ${ }^{13} \mathrm{C}$ NMR spectra showed chemical shifts at 26.92-54.84,128.60 and 139.80 ppm for Tricyclo[4.2.1.02,5]non-2(5)-ene; at60.32-73.76 ppm for cyclohexane ring; at 80.20 ppm for methylene bound to both hydroxyl and phenyl group; at 111.40-126.26 and 148.10 ppm for phenyl bound amino group; at 126.44-126.48, 129.12 and $139.96 \mathrm{ppm}$ for phenyl group bound to methylene group; at 200.40 and 200.44 ppm for ketone groups. Finally, the mass spectrum from 5 showed a molecular ion $(\mathrm{m} / \mathrm{z}) 430.18$.

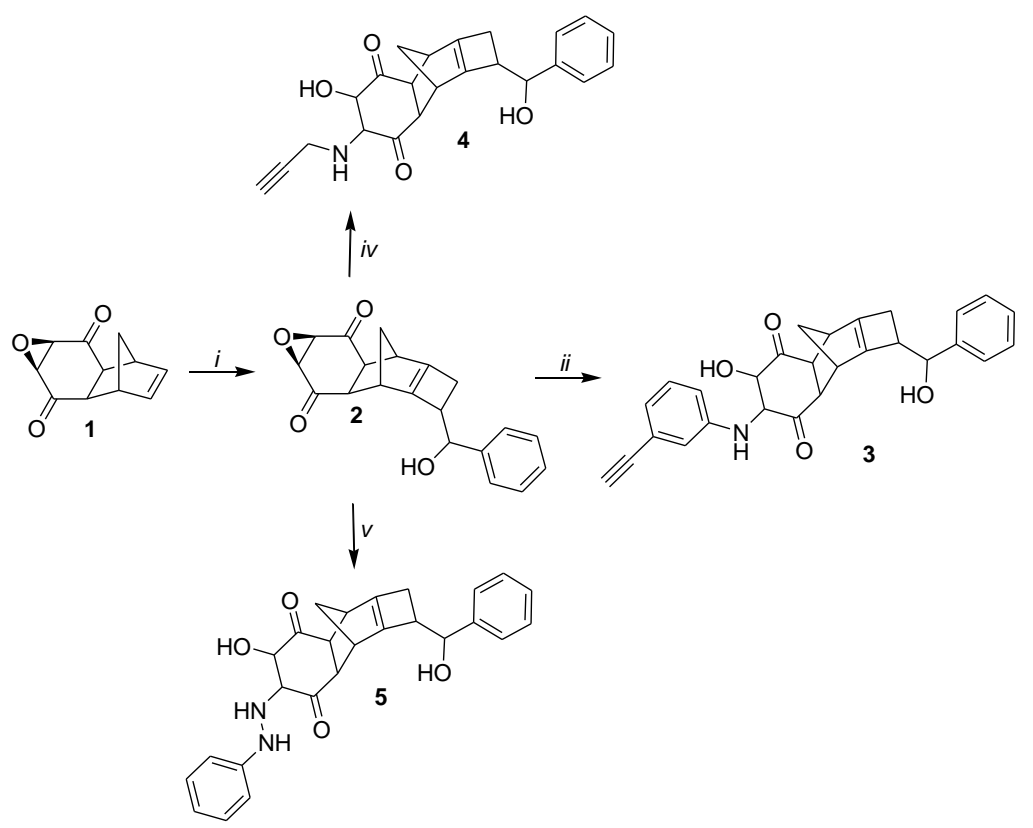

Figure 1. Synthesis of three tetracyclic-dione derivatives (3-5). Reagents and conditions; $i=1$-phenyl-2-propyn1-ol, Copper(II) chloride, methanol room temperature, $72 \mathrm{~h}$.; $i i=3$-ethynilaniline, triethylamine, water; $\mathrm{pH}=$ 11.9, reflux, 4 h. $i i=$ propargylamine, triethylamine, water; $\mathrm{pH}=11.9$, reflux, $4 \mathrm{~h} . i i=$ phenylhydrazine, triethylamine, water; $\mathrm{pH}=11.9$, reflux, $4 \mathrm{~h}$. 


\subsubsection{Pharmacophore modeling.}

Some theoretical methods have been used to predict the three-dimensional orientation adopted by the interaction protein-ligands [34]. For example, a study showed that the pharmacophore model provides a new perspective to design drugs that can be used to treat any clinical pathology [35]. In this way, in this research, the LigandScout software was used to develop a pharmacophore model for compounds 3-5. The results showed (Figure 2) different types of functional groups involved in the compounds 3-5, which may interact through either hydrophobic contacts or as hydrogen bond acceptors or as hydrogen bond donors with some biomolecules.
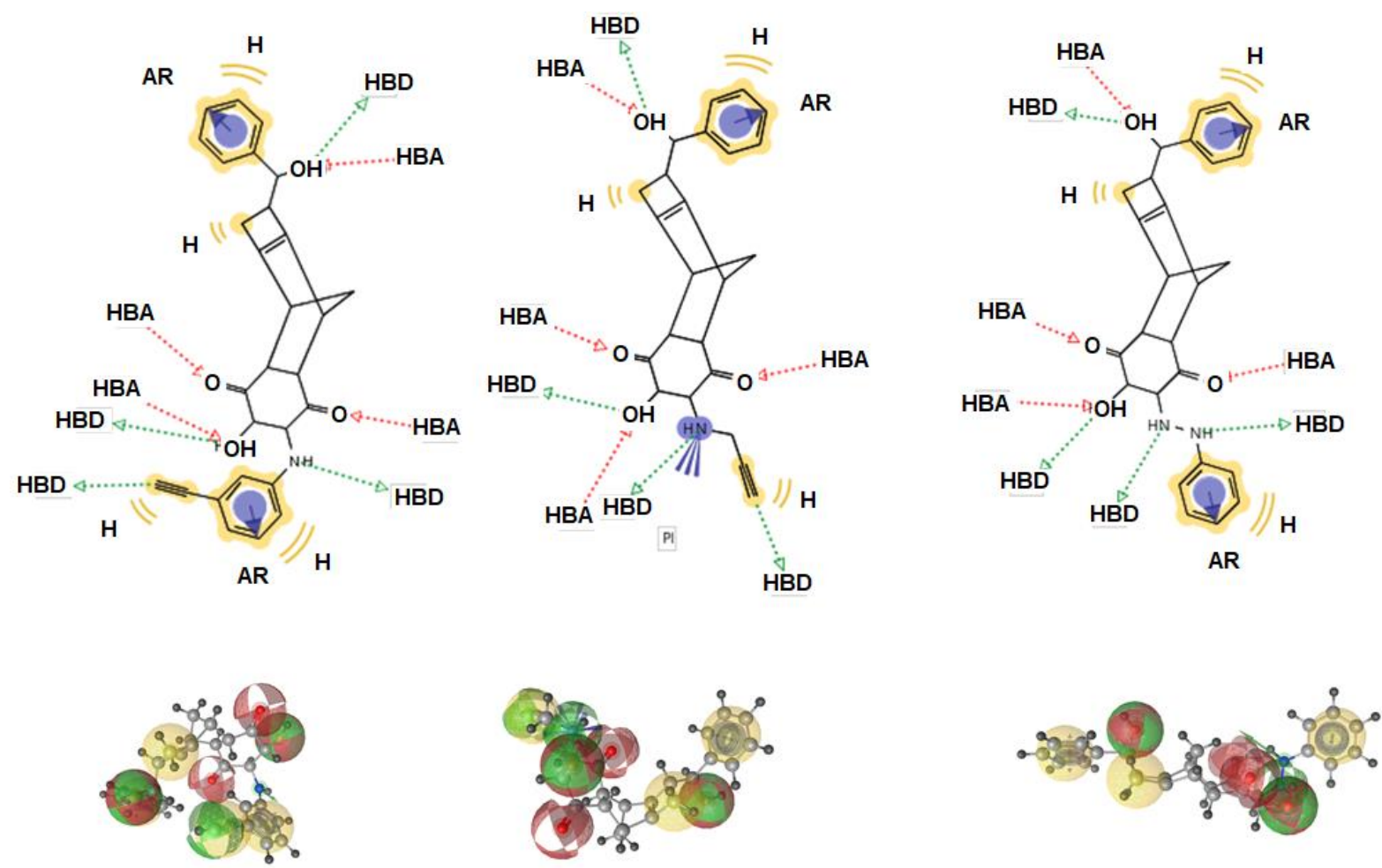

Figure 2. Scheme represents a pharmacophore from compounds 3, 4, and 5 using the LigandScout software. The model involves a methyl group (yellow) hydrogen bond acceptors (HBA, red), hydrogen bond donor (HBD, green), and a positive ionizable (PI).

\subsection{Biological activity.}

\subsubsection{General methods.}

Changes in perfusion pressure as a consequence of an increase in time in the absence (control) or presence of either tetracyclic-dione derivatives (3, 4, and 5) (Figure 3) were evaluated. The results showed that only compound 5 increase the perfusion pressure $(\mathrm{p}=0.005)$ compared with compounds 3,4 , and the conditions control. These data suggest that functional groups involved in the chemical structure of compound 5 are specific for induce changes on perfusion pressure.

By analyzing these data and other studies suggest that the effect exerted by some compounds on perfusion pressure is correlated to changes in coronary resistance [36-38]. In this way, in this research, the coronary resistance was calculated as the ratio of perfusion pressure at the coronary flow assayed $(10 \mathrm{ml} / \mathrm{min})$. The results showed that compound 5 
increase $(\mathrm{p}=0.005)$ the coronary resistance compared with either compounds 3 or 4 and the control Figure 4.

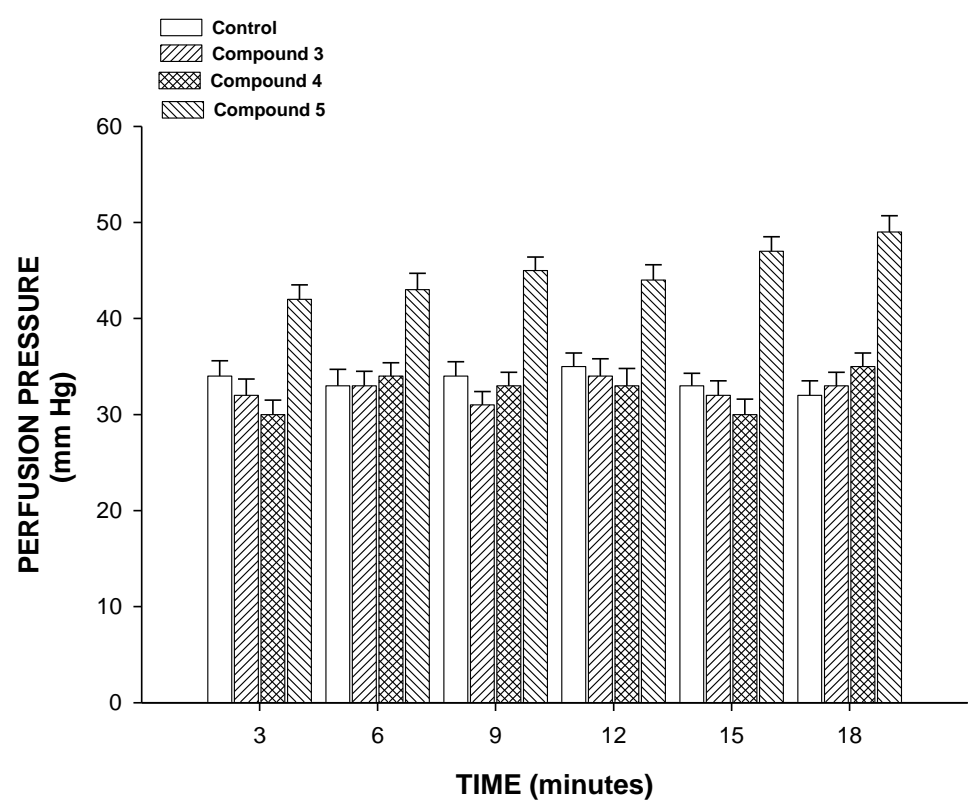

Figure 3. Effect exerted by the tetracyclic-dione derivatives (compounds 3, 4, and 5) at a dose of $0.001 \mathrm{nM}$ on perfusion pressure. The results showed that compound 5 significantly increase the perfusion pressure $(p=0.006)$ over time compared to control conditions and compounds 3 and 4 . Each bar represents the mean \pm S.E. of 8 experiments.

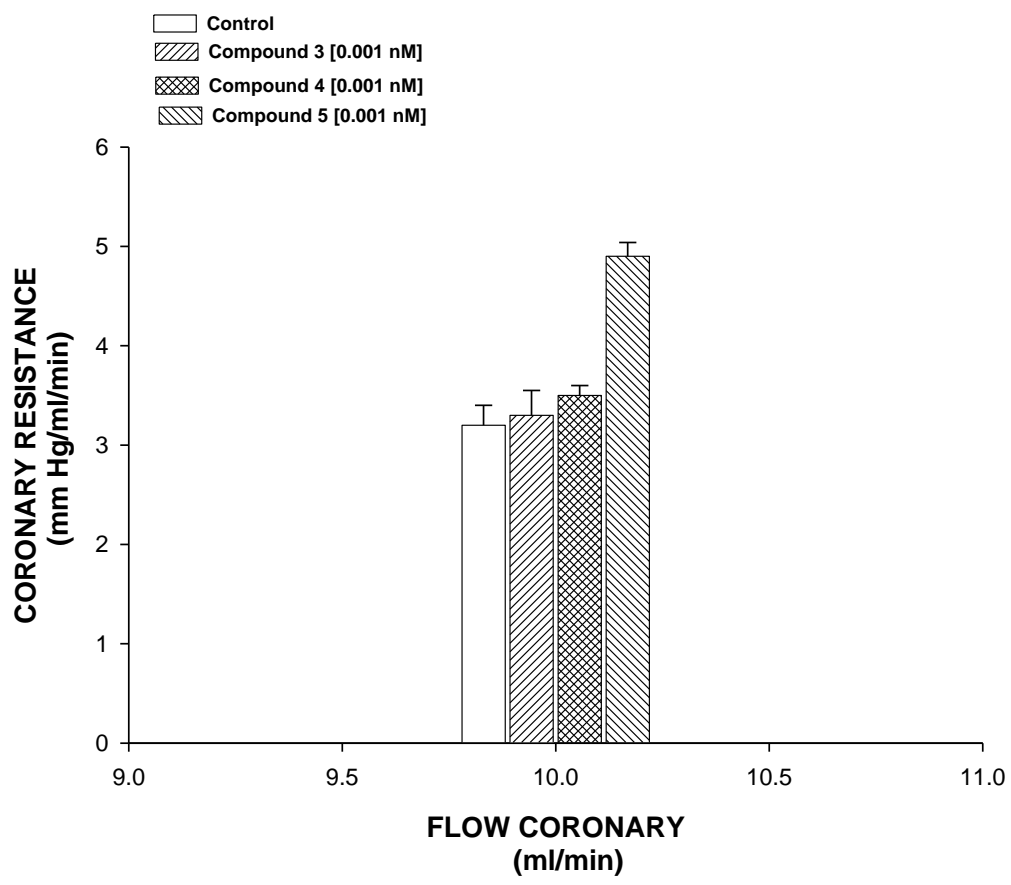

Figure 4. Activity induced by tetracyclic-dione derivatives (compounds 3, 4, and 5) on coronary resistance. The results showed that compound 5 increase $(p=0.005)$ the coronary resistance compared with either compounds 3 or 4 and the control conditions. Each bar represents the mean \pm S.E. of 8 experiments.

\subsection{Pharmacokinetic theoretical evaluation.}

Some pharmacokinetic parameters of compounds 3-5 were evaluated using SWISSADME software. The results showed that compounds 3-5 could be absorbed via oral, and compounds 3 and 5 show higher lipophilicity compared with compound 4 (Table 1). 
Besides, other data indicate differences in the interaction with CYP proteins, resulting in changes in their metabolism, such as happening with other drugs [39-41].

Table 1. The pharmacokinetics properties of compounds 2-4. The values determinate using the SwissADME

\begin{tabular}{l|c|c|c|c|c|c|c|c|c} 
Comp. & $\begin{array}{c}\text { Comp GI } \\
\text { (absorption) }\end{array}$ & $\begin{array}{c}\text { BBB } \\
\text { (permeant) }\end{array}$ & $\begin{array}{c}\text { P-gP } \\
\text { (substrate) }\end{array}$ & $\begin{array}{c}\text { CYP1A2 } \\
\text { inhibitor }\end{array}$ & $\begin{array}{c}\text { CYP2C19 } \\
\text { inhibitor }\end{array}$ & $\begin{array}{c}\text { CYP2C9 } \\
\text { inhibitor }\end{array}$ & $\begin{array}{c}\text { CYP2D6 } \\
\text { inhibitor }\end{array}$ & $\begin{array}{c}\text { CYP3A4 } \\
\text { inhibitor }\end{array}$ & $\begin{array}{c}\text { LogKp (skyn } \\
\text { permeation) } \\
\text { cm/s }\end{array}$ \\
\hline 3 & High & No & Yes & No & No & No & Yes & No & -7.55 \\
4 & High & No & Yes & No & No & No & No & No & -8.76 \\
5 & high & No & yes & No & No & No & Yes & No & -7.83
\end{tabular}

\section{Conclusions}

It's interesting the biological activity exerted by the tetracyclic-dione derivative (compound 5) on both perfusion pressure and vascular resistance. This effect could be translated as a good candidate to be evaluated as an inotropic agent. Besides, the effect exerted by this compound depends on functional groups involved in chemical structure.

\section{Funding}

This research received no external funding.

\section{Acknowledgments}

Acknowledgments to Benjamin Valverde and Raquel Anzurez for their unconditional support of this manuscript.

\section{Conflicts of Interest}

The authors declare no conflict of interest.

\section{References}

1. Zhao, H.; Yang, A.; Liu, J.; Bao, S.; Peng, R.; Hu, Y.; Hu, L. Chartspiroton, a Tetracyclic Spironaphthoquinone Derivative from a Medicinal Plant Endophytic Streptomyces. Organic Letters 2020, 22, 3739-3743, https://doi.org/10.1021/acs.orglett.0c00696.

2. Grau, L.; Romero, M.; Privat-Contreras, C.; Presa, D.; Viñas, M.; Morral, J.; Pors, K.; Rubio-Martinez, J.; Pujol, M.D. Multigram scale synthesis of polycyclic lactones and evaluation of antitumor and other biological properties. European Journal of Medicinal Chemistry 2020, 185, https://doi.org/10.1016/j.ejmech.2019.111807.

3. Hao, L.; Ma, Y.; Zhao, L.; Zhang, Y.; Zhang, X.; Ma, Y.; Yu, P. Synthesis of tetracyclic oxindoles and evaluation of their $\alpha$-glucosidase inhibitory and glucose consumption-promoting activity. Bioorganic \& Medicinal Chemistry Letters 2020, 30, https://doi.org/10.1016/j.bmcl.2020.127264.

4. Belica-Pacha, S.; Miłowska, K.; Ionov, M.; Bryszewska, M.; Buczkowski, A.; Budryn, G.; Pałecz, B. The impact of $\beta$-cyclodextrin on biological and chemical properties of mianserin hydrochloride in aqueous solution. Journal of Molecular Liquids 2020, 314, https://doi.org/10.1016/j.molliq.2020.113589.

5. Wünsch, B.; Kröger, L.; Daniliuc, C.; Ensan, D.,;Borgert, S.; Nienberg, C.; Pietsch, M. Synthesis and SAR of tetracyclic inhibitors of protein kinase CK2 derived from furocarbazole W16. ChemMedChem 2020, https://doi.org/10.1002/cmdc.202000040.

6. Ghiulai, R.; Roşca, O.; Antal, D.; Mioc, M.; Mioc, A.; Racoviceanu, R.; Şoica, C. Tetracyclic and Pentacyclic Triterpenes with High Therapeutic Efficiency in Wound Healing Approaches. Molecules 2020, 25, https://doi.org/10.3390/molecules25235557.

7. Jończyk, J.; Godyń, J,; Stawarska, E.; Morak-Młodawska, B.; Jeleń, M.; Pluta, K.; Malawska, B. Dual action of dipyridothiazine and quinobenzothiazine derivatives-Anticancer and cholinesterase-inhibiting activity. Molecules 2020, 25, https://doi.org/10.3390/molecules25112604.

8. Bingul, M.; Arndt, G.; Marshall, G.; Cheung, B.; Kumar, N.; Black, D. Synthesis, Characterization and Biological Evaluation of Novel Dihydropyranoindoles Improving the Anticancer Effects of HDAC Inhibitors. Molecules 2020, 25, https://doi.org/10.3390/molecules25061377. 
9. Zemene, T.; Meshesha, M.; Denu, D.; Abdissa, N. Tetracyclic Triterpenes from the Stem Bark of Vernonia biafrae and Evaluation of its Antimicrobial Activity. Ethiopian Journal of Education and Sciences 2020, 15, 56-64.

10. Zou, J.; Zhao, L.; Yi, P.; An, Q.; He, L.; Li, Y.; Hao, X. Quinolizidine Alkaloids with Antiviral and Insecticidal Activities from the Seeds of Sophora tonkinensis Gagnep. Journal of Agricultural and Food Chemistry 2020, 68, 15015-15026, https://doi.org/10.1021/acs.jafc.0c06032.

11. Di Braccio, M.; Grossi, G.; Roma, G.; Vargiu, L.; Mura, M.; Marongiu, M. 1, 5-Benzodiazepines. Part XII. Synthesis and biological evaluation of tricyclic and tetracyclic 1, 5-benzodiazepine derivatives as nevirapine analogues. European Journal of Medicinal chemistry 2001, 36, 935-949, https://doi.org/10.1016/S02235234(01)01283-1.

12. Yamato, M.; Takeuchi, Y.; Hashigaki, K.; Ikeda, Y.; Chang, M.; Takeuchi, K.; Tashiro, T. Synthesis and antitumor activity of fused tetracyclic quinoline derivatives. 1. Journal of medicinal chemistry 1989, 32, 1295-1300, https://doi.org/10.1021/jm00126a025.

13. Sashidhara, K.; Modukuri, R.; Jadiya, P.; Rao, K.; Sharma, T.; Haque, R.; Nazir, A. Discovery of 3arylcoumarin-tetracyclic tacrine hybrids as multifunctional agents against Parkinson's disease. ACS Medicinal Chemistry Letters 2014, 5, 1099-1103, https://doi.org/10.1021/ml500222g.

14. Al-Trawneh, S.; El-Abadelah, M.; Zahra, J.; Al-Taweel, S.; Zani, F.; Incerti, M.; Vicini, P. Synthesis and biological evaluation of tetracyclic thienopyridones as antibacterial and antitumor agents. Bioorganic \& Medicinal Chemistry 2011, 19, 2541-2548, https://doi.org/10.1016/j.bmc.2011.03.018.

15. Al-Trawneh, S.; Zahra, J.; Kamal, M.; El-Abadelah, M.; Zani, F.; Incerti, M.; Vicini, P. Synthesis and biological evaluation of tetracyclic fluoroquinolones as antibacterial and anticancer agents. Bioorganic \& Medicinal Chemistry 2010, 18, 5873-5884, https://doi.org/10.1016/j.bmc.2010.06.098.

16. Boschmans, S.; Perkin, M.; Terblanche, S.; Opie, L. The effects of imipramine, mianserin and trazodone on the chronotropic, inotropic and coronary vascular responses in the isolated perfused rat heart. General Pharmacology 1989, 20, 233-237, https://doi.org/10.1016/0306-3623(89)90022-0.

17. Boido, V.; Ercoli, M.; Tonelli, M.; Novelli, F.; Tasso, B.; Sparatore, F.; Froldi, G. New arylsparteine derivatives as positive inotropic drugs. Journal of Enzyme Inhibition and Medicinal Chemistry 2017, 32, 588-599, https://doi.org/10.1080/14756366.2017.1279156.

18. Ahn, H.; Bercovici, A.; Boykow, G.; Bronnenkant, A.; Chackalamannil, S.; Chow, J.; Zhang, H. Potent tetracyclic guanine inhibitors of PDE1 and PDE5 cyclic guanosine monophosphate phosphodiesterases with oral antihypertensive activity. Journal of Medicinal Chemistry 1997, 40, 2196-2210, https://doi.org/10.1021/jm9608467.

19. Alder, K.; Flock, F.; Beumling, H. Darstellung von p-Chinon-epoxyden. Chemische Berichte 1960, 93, 1896-1899, https://doi.org/10.1002/cber.19600930830.

20. Figueroa-Valverde, L.; Diaz-Cedillo, F.; Rosas-Nexticapa, M.; Mateu, M. Preparation of a steroid-oxazole$1,2^{\prime}-[1,3]$ oxazete] derivative: biological and theoretical evaluation of its interaction with a kinase protein (CK2). SN Applied Sciences 2019, 1, 1-12, https://doi.org/10.1007/s42452-019-0378-7.

21. Mahanthesh, M.; Ranjith, D.; Raghavendra, J.; Narappa, G.; Ravi, M. Swiss ADME prediction of phytochemicals present in Butea monosperma (Lam.) Taub. Journal of Pharmacognosy and Phytochemistry 2020, 9, 1799-1809.

22. Figueroa-Valverde, L.; Diaz-Cedillo, F.; Garcia-Cervera, E.; Pool-Gomez, E.; Lopez-Ramos, M. Susceptibility to cardiac ischemia/reperfusion injury modulated by an estrogen derivative. African Journal of Pharmacy and Pharmacology 2012, 6, 2493-2502.

23. Lauro, F.; Francisco, D.; Lenin, H.; Elodia, G.; Eduardo, P.; Marcela, R.; Bety, S. New steroid derivative with hypoglycemic activity. International Journal of Clinical and Experimental Medicine 2014, 7.

24. Li, Y.; Liu, X.; Jiang, H.; Liu, B.; Chen, Z.; Zhou, P. Palladium-CatalyzedBromoalkynylation of C-C Double Bonds: Ring-Structure-Dependent Synthesis of 7-Alkynyl Norbornanes and Cyclobutenyl Halides. Angewandte Chemie International 2011, 50, 6341-6345, https://doi.org/10.1002/anie.201100002

25. Le, D.; Morandi, G.; Legoupy, S.; Pascual, S.; Montembault, V.; Fontaine, L. Cyclobutenyl macromonomers: Synthetic strategies and ring-opening metathesis polymerization. European Polymer Journal 2013, 49, 972-983, https://doi.org/10.1016/j.eurpolymj.2013.01.008.

26. Takeda, T.; Fujii, T.; Morita, K.; Fujiwara, T. [2+ 2] Cycloaddition of Alkenyl Sulfide with $\alpha$, $\beta$-Unsaturated Ketone. A Convenient Route to 1-Cyclobutenyl Ketones. Chemistry Letters 1986, 15, 1311-1314, https://doi.org/10.1246/cl.1986.1311.

27. Harrak, Y.; Pujol, M. Mild cleavage of aliphatic epoxides with substituted anilines on alumina. Tetrahedron Letters 2002, 43, 819-822, https://doi.org/10.1016/S0040-4039(01)02280-8.

28. Zhao, P.-Q.; Xu, L.-W.; Xia, C.-G. Transition Metal-based Lewis Acid Catalyzed Ring Opening of Epoxides Using Amines under Solvent-Free Conditions. Synlett 2004, 5, 846-850, https://doi.org/10.1055/s-2004817780 .

29. Cossy, J.; Bellosta, V.; Hamoir, C.; Desmurs, J. Regioselective ring opening of epoxides by nucleophiles by lithium bis-trifluoromethanesulfonimide. Tetrahedron Letters 2002, 43, 7083-7086, https://doi.org/10.1016/S0040-4039(02)01533-2. 
30. Ollevier, T.; Lavie-Compin, G. Bismuth triflate-catalyzed mild and efficient epoxide opening by aromatic amines under aqueous conditions. Tetrahedron Letters 2004, 45, 49-52, https://doi.org/10.1016/j.tetlet.2003.10.129.

31. Ollevier, T.; Lavie-Compin, G. An efficient method for the ring opening of epoxides with aromatic amines catalyzed by bismuth trichloride . Tetrahedron Letters 2002, 43, 7891-7893, https://doi.org/10.1016/S00404039(02)01896-8.

32. Shivani, B.; Chakraborti, A. Zinc(II) Perchlorate Hexahydrate Catalyzed Opening of Epoxide Ring by Amines: Applications to Synthesis of (RS)/(R)-Propranolols and (RS)/(R)/(S)-Naftopidils. Journal of Organic Chemistry 2007, 72, 3713-3722, https://doi.org/10.1021/jo062674j.

33. Rampalli, S.; Chaudhari, S.; Akamanchi, K. Diisopropoxyaluminium Trifluoroacetate: A New Promoter for Aminolysis of Epoxides. Synthesis 2000, 1, 78-80, https://doi.org/10.1055/s-2000-6235.

34. Porey, S.; Zhang, X.; Bhowmick, S.; Kumar, V.; Guin, S.; Paton, R.; Maiti, D. Alkyne linchpin strategy for drug: pharmacophore conjugation: experimental and computational realization of a meta-selective inverse Sonogashira coupling. Journal of the American Chemical Society 2020, 142, 3762-3774, https://doi.org/10.1021/jacs.9b10646.

35. Lestari, K.; Sitorus, T.; Instiaty, S.; Levita, J. Molecular Docking of Quinine, Chloroquine and Hydroxychloroquine to Angiotensin Converting Enzyme 2 (ACE2) Receptor for Discovering New Potential COVID-19 Antidote. Journal of Advanced Pharmacy Education \& Research 2020, 10, 1-4.

36. Figueroa-Valverde, L.; Diaz-Cedillo, F.; Rosas-Nexticapa, M.; Garcimarrero, A.; Lopez-Ramos, M. Synthesis and Biological Activity of a Bis-steroid-methanocyclobuta-naphthalene-dione Derivative against Ischemia/Reperfusion Injury via Calcium Channel Activation. Anti-Inflammatory \& Anti-Allergy Agents in Medicinal Chemistry 2020, 19, 393-412, https://doi.org/10.2174/1871523018666191003152854

37. Kobayashi, J.; Luo, S.; Akazawa, Y.; Parker, M.; Wang, J.; Chiasson, D.; Honjo, O. Flow-targeted pediatric ex vivo heart perfusion in donation after circulatory death: A porcine model. The Journal of Heart and Lung Transplantation, 2020, 39, 267-277, https://doi.org/10.1016/j.healun.2019.11.023.

38. Figueroa-Valverde, L.; Diaz-Cedillo, F.; Rosas-Nexticapa, M.; Mateu, V.; Garcimarrero, A.; Oke Y. Design and synthesis of new azetidine-steroid derivative with inotropic activity in a heart failure model. Vietnam Journal of Chemistry 2020, 58, 10-19, https://doi.org/10.1002/vjch.201900131.

39. Hakkola, J.; Hukkanen, J.; Turpeinen, M.; Pelkonen, O. Inhibition and induction of CYP enzymes in humans: an update. Archives of Toxicology 2020, 94, 3671-3722, https://doi.org/10.1007/s00204-020-02936-7.

40. Siam, M.; Sarker, A.; Sayeem, M.; In silico drug design and molecular docking studies targeting Akt1 (RACalpha serine/threonine-protein kinase) and Akt2 (RAC-beta serine/threonine-protein kinase) proteins and investigation of CYP (cytochrome P450) inhibitors against MAOB (monoamine oxidase B) for OSCC (oral squamous cell carcinoma) treatment. Journal of Biomolecular Structure and Dynamics 2020, 1-13, https://doi.org/10.1080/07391102.2020.1802335.

41. Jinhua, W.; Ying, Z.; Yuhua, L. PXR-ABC drug transporters/CYP-mediated ursolic acid transport and metabolism in vitro and vivo. Archiv der Pharmazie 2020, 353, https://doi.org/10.1002/ardp.202000082. 